\title{
Studies on Maize Yield under Drought Using Correlation and Path Coefficient Analysis
}

\author{
Asima Gazal ${ }^{\text {* }}$, Zahoor Ahmed Dar ${ }^{2}$, Ajaz Ahmad Lone ${ }^{3}$, \\ Nida Yousuf ${ }^{1}$ and Shazia Gulzar ${ }^{1}$
}

\author{
${ }^{1}$ Division of Genetics and Plant Breeding, SKUAST-K, J\&K, India \\ ${ }^{2}$ Dryland Agricultural Research Station, SKUAST-K, Budgam, J\&K, India \\ ${ }^{3}$ Saffron Research Station, Pampore, SKUAST-K, J\&K, India
}

*Corresponding author

K e y w o r d s
Correlation, Yield,
$\begin{aligned} & \text { Zea mays L., Path, } \\ & \text { Drought }\end{aligned}$
Article Info
$\begin{aligned} & \text { Accepted: } \\ & \text { 06 December } 2017 \\ & \text { Available Online: } \\ & \text { 10 January } 2018\end{aligned}$

\section{A B S T R A C T}

Yield being a complex character is governed by a large number of genes. To evaluate the relationship between yield and its components in maize through correlation and path studies a study was conducted. In present investigation, it was inferred that genotypic and phenotypic correlations among ten morpho-physiological and yield traits in maize lines were significant. The grain yield plot $^{-1}$ was positively correlated with 100 -seed weight, ears plot ${ }^{-1}$, chlorophyll content, plant height, ear height and number of kernels row $^{-1}$ indicating the importance of these traits in selection for yield. The influence of each character on yield could be known through correlation studies with a view to determine the extent and nature of relationships prevailing among yield and yield attributing characters. Path-coefficient analysis was studied at phenotypic level considering grain yield plot $^{-1}$ as dependent character. The independent characters were plant height $(\mathrm{cm})$, ear height $(\mathrm{cm})$, leaf relative water content $(\%)$, chlorophyll content at flowering, chlorophyll content at maturity, ears plant ${ }^{-1}$, kernels row $^{-1}, 100$ grain weight $(\mathrm{g})$, protein content $(\%)$. The highest positive and direct effect was found for chlorophyll content at flowering, kernels row ${ }^{-1}$ followed by 100 grain weight and plant height. These traits contributed maximum to higher grain yield compared to other characters, thus, selection for these characters helps in selection of superior cross combinations for improvement of yield.

\section{Introduction}

Maize (Zea mays L.) is among the third most important cereal crops in India after rice and wheat meeting $50-60 \%$ of requirements of the people. It provides food, feed, fodder, fuel and serves as a raw material for many industrial products viz., starch, oil, and biofuel etc. It has wide adaptability to diverse agro-ecologies over latitude of $58 \mathrm{~N}$ to $40 \mathrm{~S}$, and to a $3000 \mathrm{~m}$ altitude above mean sea level and thrives well in areas receiving rainfall ranging from 250 to $5000 \mathrm{~mm}$ (Downsell et al., 1996). Drought is one among the most important abiotic stress factors (Bruce et al., 2002), affecting growth and development of plants. The best option for good production, crop yield improvement and yield stability under drought stress conditions 
is to develop drought tolerant crop varieties. One of the major goals of drought breeding programs is selection of the lines/cultivars/genotypes which are performing best under stress conditions. However, low heritability of drought tolerance and complex nature along with lack of effective selection procedures limit development of resistant crop cultivars to stress. Drought stress coinciding with flowering delays silking and results in an increase of anthesis-silking interval (Bolaòos et al., 1993); this usually gets associated with reduction in grain number and yield. Grain yield being a complex quantitative character is governed by many genes.

The traits influencing yield are understood through correlation studies to determine the nature and extent of relationships between yield and other yield attributing traits. Yield improvement and stability is the primary objective of a plant breeder. Therefore, correlation analysis of a particular trait with other trait attributing to yield is of great importance for selecting lines for higher yield. Path coefficient analysis helps partitioning the correlation coefficient into its direct and indirect effects. This experiment was conducted to estimate the genotypic and phenotypic correlations and direct and indirect contributions of different traits to yield.

\section{Materials and Methods}

Study material comprised of 100 maize inbred lines available at AICRP (All India Coordinated Research Programme) Maize Srinagar Centre, collected from CIMMYT (International Maize and Wheat Improvement Centre) Mexico, AAU, Anand, IIMR, New Delhi, and MPUAT, Udaipur. These inbred lines were planted in a factorial randomized complete block design with two replications over two years. Each inbred line was planted in two row experimental plot of 1 metre length with inter and intra row spacing of $60 \times 20$ $\mathrm{cm}$. The lines were evaluated under well watered and watered stressed conditions with two replications over two years. The data was recorded on plant height $(\mathrm{cm})$, ear height $(\mathrm{cm})$, leaf relative water content (\%), chlorophyll content at flowering (SPAD units), chlorophyll content at maturity(SPAD units), ears plant ${ }^{-1}$, kernels row $^{-1}$, 100 grain weight (g) and protein content (\%). Observations were recorded on five randomly selected plants from each plot in each replication. Selected plants were tagged before tasseling.

Statistical analysis viz., correlation coefficient was carried out to understand the association and relationships between the traits, genotypic and phenotypic correlations coefficient were worked out by adopting method described by Singh and Chaudhary (1977). The genotypic and phenotypic correlation coefficient was partitioned into direct and indirect effects by path analysis to establish cause and effect association between the traits as suggested by Dewey and Lu (1959).

\section{Results and Discussion}

Genotypic and phenotypic correlations among ten morpho-physiological and yield traits in maize lines were computed. The data (Table 1) revealed that significant genotypic correlations and they were slightly higher in magnitude than phenotypic ones. This indicated that though there was a strong inherent association between characters studied, its expression was lessened due to the influence of environment. But, there was a general agreement in both sign and magnitude between the estimates of genotypic and phenotypic correlations. The grain yield plot $^{-1}$ was positively correlated with 100-seed weight, ears plot $^{-1}$, chlorophyll content, plant height, ear height and number of kernels row ${ }^{-}$ ${ }^{1}$ indicating the importance of these traits in selection for yield. 
Table.1 Correlation coefficients for different traits in inbred lines of maize (pooled over years)

\begin{tabular}{|c|c|c|c|c|c|c|c|c|c|c|}
\hline Traits & PH & EH & LRWC & $\mathrm{CCF}$ & CCM & EPP & KPR & $100 \mathrm{GW}$ & GYP & PC \\
\hline PH & 1.00 & $0.997 * *$ & $0.552 * *$ & $0.697 * *$ & $0.703 * *$ & $0.775^{* *}$ & $0.659 * *$ & $0.775 * *$ & $0.804 * *$ & $0.644 * *$ \\
\hline EH & $0.962 * *$ & 1.00 & $0.549 * *$ & $0.706 * *$ & $0.703 * *$ & $0.771 * *$ & $0.651 * *$ & $0.767 * *$ & $0.796 * *$ & $0.651 * *$ \\
\hline LRWC & $0.492 * *$ & $0.47 * *$ & 1.00 & $0.559 * *$ & $0.569 * *$ & $0.594 * *$ & $0.485 * *$ & $0.578 * *$ & $0.574 * *$ & $0.449 * *$ \\
\hline CCF & $0.644 * *$ & $0.626 * *$ & $0.548 * *$ & 1.00 & $0.934 * *$ & $0.781 * *$ & $0.625 * *$ & $0.729 * *$ & $0.805 * *$ & $0.609 * *$ \\
\hline CCM & $0.56^{* *}$ & $0.541 * *$ & $0.572 * *$ & $0.895 * *$ & 1.00 & $0.893 * *$ & $0.832 * *$ & $0.812 * *$ & $0.776 * *$ & $0.562 * *$ \\
\hline EPP & $0.615^{* *}$ & $0.595 * *$ & $0.548 * *$ & $0.757 * *$ & $0.879 * *$ & 1.00 & $0.914 * *$ & $0.926 * *$ & $0.861 * *$ & $0.645^{* *}$ \\
\hline KPR & $0.475 * *$ & $0.452 * *$ & $0.502 * *$ & $0.621 * *$ & $0.878 * *$ & $0.887 * *$ & 1.00 & $0.846 * *$ & $0.719 * *$ & $0.486 * *$ \\
\hline $100 \mathrm{GW}$ & $0.675^{* *}$ & $0.647 * *$ & $0.579 * *$ & $0.742 * *$ & $0.832 * *$ & $0.902 * *$ & $0.848 * *$ & 1.00 & $0.912 * *$ & $0.677 * *$ \\
\hline GYP & $0.764 * *$ & $0.733 * *$ & $0.502 * *$ & $0.768 * *$ & $0.652 * *$ & $0.746^{* *}$ & $0.567 * *$ & $0.837 * *$ & 1.00 & $0.732 * *$ \\
\hline PC & $0.614 * *$ & $0.602 * *$ & $0.408 * *$ & $0.599 * *$ & $0.497 * *$ & $0.575^{* *}$ & $0.407 * *$ & $0.641 * *$ & $0.716 * *$ & 1.00 \\
\hline
\end{tabular}

** Significant at 1 per cent level. Plant height $(\mathrm{cm})=\mathrm{PH}$, Ear height $(\mathrm{cm})=\mathrm{EH}$, Leaf relative water content $(\%)=$ LRWC, Chlorophyll content at flowering= $\mathrm{CCF}$, Chlorophyll content at maturity $=\mathrm{CCM}$, Ears plant ${ }^{-1}=\mathrm{EPP}$, Kernels row ${ }^{-1}=\mathrm{KPR}, 100$ Grain weight $(\mathrm{g})=100 \mathrm{GW}$, Grain yield plot ${ }^{-1}=\mathrm{GYP}$, Protein content $(\%)=\mathrm{PC}$

Table.2 Direct and indirect effects (genotypic level) of morphological, physiological yield attributing and quality traits on grain yield $\operatorname{plot}^{-1}(\mathrm{~g})$ in inbred lines of maize (pooled over years)

\begin{tabular}{|l|l|l|l|l|l|l|l|l|l|l|} 
Traits & PH & EH & LRWC & CCF & CCM & EPP & KPR & 100 GW & PC & GCC \\
\hline PH & $\mathbf{0 . 4 6 0 2}$ & -0.4218 & 0.0005 & 1.0337 & -1.1919 & 0.1426 & 0.3745 & 0.3893 & 0.0172 & 0.8042 \\
\hline EH & 0.4590 & $\mathbf{- 0 . 4 2 2 9}$ & 0.0005 & 1.0377 & -1.1908 & 0.1418 & 0.3691 & 0.3850 & 0.0174 & 0.7968 \\
\hline LRWC & 0.2543 & -0.2322 & $\mathbf{0 . 0 0 0 9}$ & 0.8286 & -0.9642 & 0.1094 & 0.2755 & 0.2902 & 0.0120 & 0.5745 \\
\hline CCF & 0.3211 & -0.2963 & 0.0005 & $\mathbf{1 . 4 8 1 1}$ & -1.5827 & 0.1438 & 0.3553 & 0.3661 & 0.0162 & 0.8052 \\
\hline CCM & 0.3238 & -0.2973 & 0.0005 & 1.3840 & $\mathbf{- 1 . 6 9 3 8}$ & 0.1643 & 0.4728 & 0.4067 & 0.0150 & 0.7760 \\
\hline EPP & 0.3567 & -0.3261 & 0.0006 & 1.1577 & -1.5131 & $\mathbf{0 . 1 8 3 9}$ & 0.5193 & 0.4651 & 0.0171 & 0.8611 \\
\hline KPR & 0.3036 & -0.2749 & 0.0005 & 0.9269 & -1.4105 & 0.1682 & $\mathbf{0 . 5 6 7 7}$ & 0.4251 & 0.0130 & 0.7195 \\
\hline $\mathbf{1 0 0}$ GW & 0.3569 & -0.3244 & 0.0005 & 1.0804 & -1.3723 & 0.1704 & 0.4808 & $\mathbf{0 . 5 0 1 9}$ & 0.0181 & 0.9123 \\
\hline PC & 0.2964 & -0.2755 & 0.0004 & 0.9020 & -0.9521 & 0.1178 & 0.2761 & 0.3403 & $\mathbf{0 . 0 2 6 6}$ & 0.7321 \\
\hline
\end{tabular}

Genotypic correlation coefficient $=\mathrm{GCC}$,

Residual effect $=0.2093 \mathrm{R}^{2}=0.9562$ 
Fig. 1

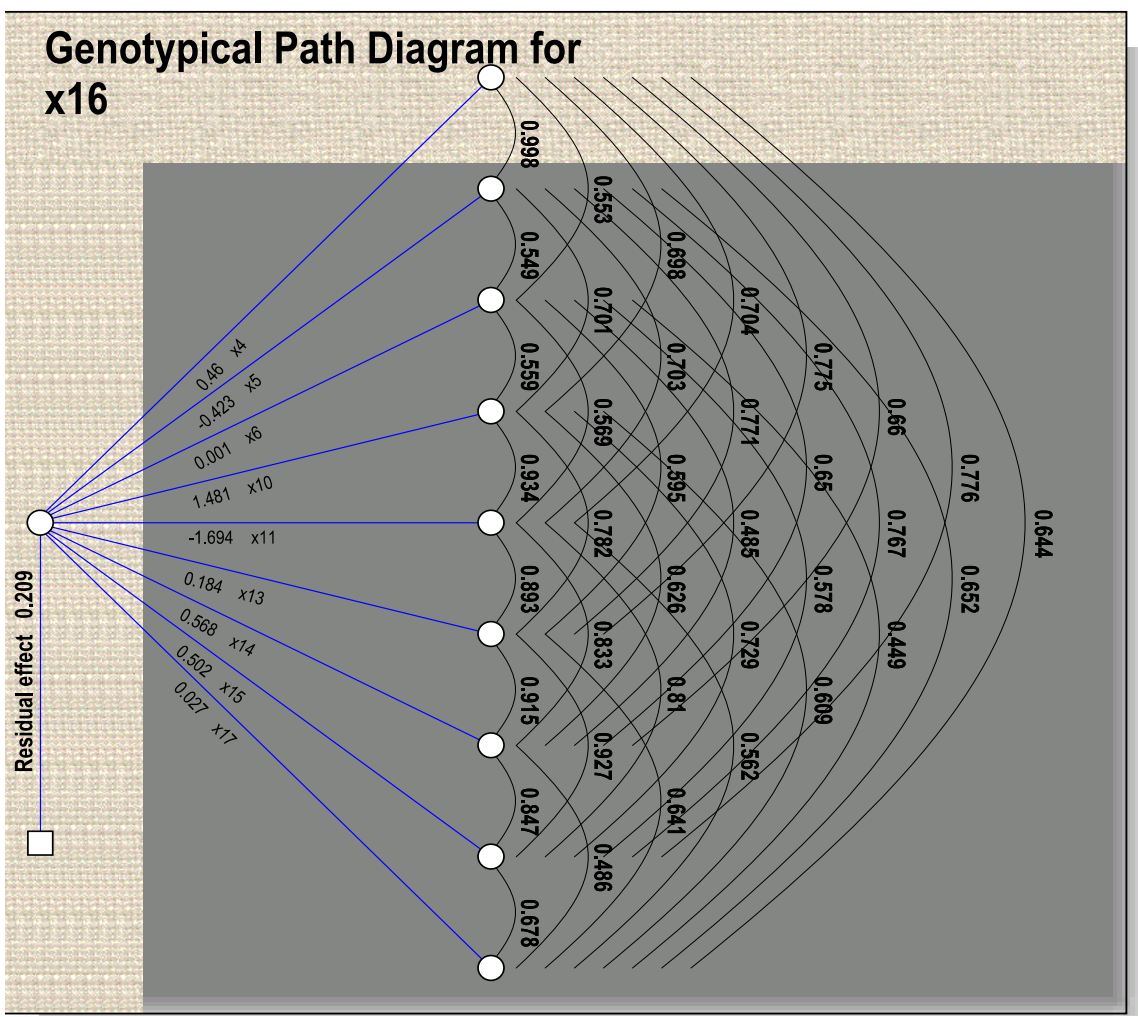

Plant height $(\mathrm{cm})=\mathrm{x} 4$, Ear height $(\mathrm{cm})=\mathrm{x} 5$, Leaf relative water content $(\%)=x 6$, Chlorophyll content at flowering $=$ $\mathrm{x} 10$, Chlorophyll content at maturity $=\mathrm{x} 11$, Ears plant $^{-1}=\mathrm{x} 13$, Kernels row $^{-1}=\mathrm{x} 14,100$ Grain weight $(\mathrm{g})=\mathrm{x} 15$, Grain yield $\operatorname{plot}^{-1}=x 16$, Protein content $(\%)=x 17$.

These observations are in conformity with the findings of Kumar et al., (2006) and Pavan et al., (2011), Dar et al., (2015), Jakhar et al., (2017a). On studying association and inter relationships among the traits other than grain yield plot $^{-1}$ which might aid in understanding an idea of plant type it was revealed that plant height had highly significant positive correlation with ear height and grain yield plot $^{-1}$. Similar observations were reported by Bhole and Patil (1984) and Jakhar et al., (2017a). Chlorophyll content at maturity had good correlation with ears plot $^{-1}$.

Path-coefficient analysis was studied at phenotypic level considering grain yield plot $^{-1}$ as dependent character. The independent characters were plant height $(\mathrm{cm})$, ear height $(\mathrm{cm})$, leaf relative water content (\%), chlorophyll content at flowering, chlorophyll content at maturity, ears plant ${ }^{-1}$, kernels row ${ }^{-1}$, 100 grain weight $(\mathrm{g})$, protein content $(\%)$. The phenotypic correlation was partitioned into direct and indirect effects on grain yield plot $^{-1}$ (Figure 1) and the data is presented in Table 2. Correlation coefficient estimates indicate only the extent and nature of association between yield and its attributes, but does not show the direct and indirect effects of different yield traits on yield per se.

Grain yield is dependent on several characters which are mutually associated; these will in turn impair the true association exiting between a component and grain yield. A change in any one component is likely to disturb the whole network of cause and effect. Thus, each component has two paths of action viz., the direct influence on grain yield, indirect effect through components which are 
not revealed from the correlation studies. The highest positive and direct effect was found for chlorophyll content at flowering (1.4811), kernels per row (0.5677) followed by 100 grain weight (0.5019), plant height (0.4602). The negative and direct effect was found for days to chlorophyll content at maturity (1.6938) and ear height (- 0.4229). The plant height showed negative indirect effect for ear height (-0.42) followed by chlorophyll content at maturity (-1.19) with positive indirect effect for ears plot $^{-1}(0.14)$, kernels row $^{-1}(0.37)$ and 100 grain weight $(0.38)$.

Ears plot $^{-1}$ showed highly positive indirect effect for chlorophyll content at flowering (1.15), kernels row $^{-1}(0.51)$ followed by 100 grain weight (0.46). The 100 grain weight showed highly positive indirect effect for chlorophyll content at flowering (1.08) followed by kernels row $^{-1}(0.48)$ and highly negative indirect effect was found for chlorophyll content at maturity (-1.37) followed by ear height (-0.32). These findings were in agreement with reports of Venugopal et al., (2003), Sofi and Rather (2007), Brar et al., (2008) Saidaiah et al., (2008) and Jakhar et al., (2017b).

Based on the findings in this study, we concluded that traits viz., 100-seed weight, ears plot $^{-1}$, chlorophyll content, plant height, ear height and number of kernels row $^{-1}$ are highly correlated with grain yield plot $^{-1}$ and need to be considered for selection. The conclusions revealed that there is scope for simultaneous improvement of these traits through selection. The highest positive and direct effects of chlorophyll content at flowering, kernels row $^{-1}$ followed by 100 grain weight and plant height was revealed on grain yield plot $^{-1}$. These traits contributed maximum to higher grain yield compared to other characters, thus, selection for these characters helps in selection of superior cross combinations for improvement of yield.

\section{References}

Bhole, G.R. and Patil, R.C. 1984. Genotypic and phenotypic correlations in maize. Journal of Maharashtra Agricultural Universities, 9: 250-251.

Bolanos, J. and Edmeades, G.O. 1993. Eight cycles of selection for drought tolerance in lowland tropical maize. II. Responses in reproductive behaviour. Field Crops Research, 31: 253-268.

Brar, S.P.S, Chawla, J.S and Singh, P. 2008. Studies on different selection indices and path analysis in maize (Zea mays L.). Crop Improvement, 35(1): 16-19.

Bruce, W.B., Edmeades, G.O. and Baker, T.C. 2002. Molecular and physiological approach to maize improvement for drought tolerance. Journal of Experimental Botany, 53: 13-25.

Dar, Z.A., Lone, A.A., Alaie, B.A., Ali, G., Gazal, A., Gulzar, S. and Yousuf, N. 2015. Correlation studies in temperate maize (Zea mays L.) Inbred lines. Plant Archives 15(2): 1191-1194.

Dewey, D.R. and Lu, H.K. 1959. A correletion and path coefficient analysis of components of creasted wheat grass and seed production. Agronomy Journal, 51: 515-518.

Dowswell, C.R., Paliwal, R.L. and Cantrell, R.P. 1996. Maize in the third world. Westview Pres Division of Harper Collins Publishers.

Jakhar, D.S., Singh, R., Ojha, V.K. and Kumar, S. 2017a. Correlation studies in maize (Zea mays L.) for yield and other yield attributing characters. International Journal of Advanced Biological Research, 7(2): 246-248.

Jakhar, D.S., Singh, R., and Kumar, A. 2017b. studies on path coefficient analysis in maize (Zea mays L.) for grain yield and its attributes. Int.J.Curr.Microbiol. App.Sci., 6(4): 2851-2856.

Kumar, S., Shahi, J.P., Singh, J. and Singh, 
S.P. 2006. Correlation and path analysis in early generation inbreds of maize (Zeamays L.). Crop Improvement. 33 (2): 156-160.

Pavan, R., Lohithaswa, H.C., Wali, M.C., Gangashetty Prakash and Shekara, B.G. 2011. Correlation and path analysis of grain yield and yield contributing traits in single cross hybrids of maize (Zea mays L.). Electronic Journal of Plant Breeding. 2(2): 253-257.

Saidaiah, P., Satyanarayana, E. and Kumar, S.S. 2008. Association and path coefficient analysis in maize (Zea mays L.). Agricultural Science Digest, 28: 79-
83.

Singh, R.K. and Chaudhary, D.D. 1977. Biometrical methods in quantitative genetic analysis. Kalyni Publishers, New Delhi. pp 288.

Sofi, P.A. and Rather, A.G. 2007. Studies on genetic variability, correlation and path analysis in maize (Zea mays L.). MaizeGenetics-Cooperation- Newsletter (81): 26-27.

Venugopal, M., Ansari, N.A. and Rajanikanth, T. 2003. Correlation and path analysis in maize (Zea mays L.). Crop Res., Hisar, 25(3): 525-529.

\section{How to cite this article:}

Asima Gazal, Zahoor Ahmed Dar, Ajaz Ahmad Lone, Nida Yousuf and Shazia Gulzar. 2018. Studies on Maize Yield under Drought Using Correlation and Path Coefficient Analysis. Int.J.Curr.Microbiol.App.Sci. 7(01): 516-521. doi: https://doi.org/10.20546/ijcmas.2018.701.062 